\title{
The Impact of Quality Management on Business Performance of Manufacturing Firms: The Moderated Effect of Industry 4.0
}

\author{
DOI: 10.12776/QIP.V25I3.1623
}

Nu Nguyen, Chuong Nguyen, Hieu Nguyen, Van Nguyen

Received: 2021-11-07 Accepted: 2021-11-28 Published: 2021-11-30

\begin{abstract}
Purpose: The research aims to investigate the individual quality management (QM) factors impact on business performance in manufacturing firms. We then assess their influence and look at how industry 4.0 affects business performance directly. Furthermore, the study will demonstrate the moderate effect of industry 4.0 on the interaction between QM and business performance.

Methodology/Approach: The authors used two methodologies. The first is qualitative methods, by interviewing experts to develop a realistically appropriate model. The second is quantitative methods, by carrying out the survey and getting 84 observations. This research used the multivariate data analysis technique PLS-SEM to evaluate three measurement models: formative measurement model, reflective measurement model, and structural model.
\end{abstract}

Findings: The QM was operationalised as a multi-dimensional construct. According to the findings, these individual QM factors significantly affect the organisation's performance, including customer satisfaction, employee satisfaction and quality performance. Besides, QM and Industry 4.0 have directly impact on performance. The study also shows that industry 4.0 has a positive moderating role in the relationship between QM and business performance.

Research Limitation/Implication: The survey was only done in emerging countries and the sample size is limited. There are other QM and business performance measurement parameters that have not yet to be discussed.

Originality/Value of paper: The study contributes to the QM literature by building a business quality model, in which the role of Industry 4.0 was explored.

Category: Research paper

Keywords: quality management; performance; manufacturing; Industry 4.0 


\section{INTRODUCTION}

With the increasingly outstanding development of the current globalised economy, it is required that the production and business process be accurate and cost-effective. In that context, the application of quality management (QM) to ensure the above requirements is extremely necessary. Quality experts have proposed several approaches through a set of QM practices. Several researchers have attempted to clarify that implementing quality management through QM practices impacts business performance (Ahire and Dreyfus, 2000; Madu, Kuei and Jacob, 1995; Magd, Negi and Ansari, 2021). It is widely applied in developed countries and has been proven to be a vital factor in determining business performance (Jaafreh and Al-abedallat, 2013) and enhancing the competitiveness of enterprises (Douglas and Judge, 2017). Many studies have investigated the relationship between the factors of quality management based on QM and business performance. Most of which have demonstrated that QM has a positive effect on business performance, referring to Benavides-Velasco, Quintana-García and Marchante-Lara (2014), Choi and Eboch (1998), Xu et al. (2020), Talib, Rahman and Qureshi (2013). There are many studies by authors in developed countries that have studied QM affecting performance, but in emerging countries (Vietnam, for example), this issue has not been properly paid attention. By applying the PLS-SEM analysis method, this study has theoretically contributed to re-affirming the relationship between QM and business performance and analysing individual QM factors to business performance.

In this study, the authors used industry 4.0 as a moderator variable for the model and the QM-based approach to conducting the research. Industry 4.0 is a new phase in the Industrial Revolution that primarily focuses on connectivity, automation, machine learning, and real-time data. Over a decade, industry 4.0 has been widely applied globally and started to be applied in Vietnam manufacturing enterprises in recent years. However, the role of technology 4.0 for manufacturing enterprises in emerging countries has been unexplored. Therefore, this study will focus on three questions: Will the adoption of industry 4.0 tools lead to more effective QM implementation; If the enterprise implements QM under the support of industry 4.0, will it achieve better business results? In other words, does industry 4.0 moderate the relationship between QM and business performance?; And finally, analysing how do individual QM factors affect business performance?

\section{LITERATURE REVIEW AND HYPOTHESES}

\subsection{Quality Management Factors}

Quality management is a long-standing concept, and many researchers analyse it (Talib, Rahman and Qureshi, 2013). QM is represented by many different factors. In this study, QM was operationalised as a multi-dimensional construct, 
including leadership, strategic planning, processes and products QM, people management, customer focus, information and analysis systems, and supplier QM.

Leadership: Kotter (1988) believed that leadership is not just an individual quality, but a process. According to the above definition, this process must be voluntary and obeyed by colleagues. Zaleznik (2004) argued that leadership requires the use of power to influence the thoughts and actions of other individuals. These discussions have helped to develop a new definition of leadership from the authors' perspective that, in different contexts, individuals appear to be capable of guiding the collective to achieve goals in different ways is considered leadership. Leadership is positively related to the operational and overall performance of the organisation through a variety of approaches, such as reward level, leadership commitment, cross cooperation between parts (Xu et al., 2020). Leadership creates motivation for open communication and continuous improvement among employees, thereby creating potential to improve organisational performance (Nair, 2006). Hypothesis H1 is proposed:

H1: Leadership has a positive effect on performance.

Strategic planning: The definitions of strategic planning are numerous, but they all have one thing in common: a defined and identifiable set of activities (Nickols, 2016). According to Nickols (2016), strategy is the determination of the short or long-term goals of an enterprise and the sequence of actions to allocate resources to realise those goals. According to Kerzner (2001), strategic planning is the process of forming decisions about the future direction of an enterprise and options to support its implementation in the right direction and it is closely related to the success of the project and the company. Jaafreh and Al- abedallat (2013) indicate that strategic planning have a significant impact on organisational performance. Indeed, many studies have found a significant relationship between strategic planning and quality performance (Prajogo, 2005), organisational effectiveness (Sila, 2003). Hypothesis H2 is proposed:

$\mathrm{H} 2$ : $\quad$ Strategic planning has a positive effect on performance.

Processes and products QM: According to Palmberg (2009), a process is a sequence of activities that turn inputs (needs) into outputs (standards) to satisfy the needs of customers. Based on the different nature of products and related processes, the QM system changes dynamically (Nilsson, Johnson and Gustafsson, 2001). Product quality is a fundamental factor that has an impact on motivating customers' buying behaviour in a variety of choices, which is the main factor affecting business results (Filip and Marascu-Klein, 2013). Yang (2006) found that process management has positive effects on customer satisfaction, by which companies can gain competitive advantage. Fotopoulos and Psomas (2010) insisted that processes and product quality are significant effects on market benefits and financial performance improvement. 
Hypothesis $\mathrm{H} 3$ is proposed:

H3: Process and product quality management have a positive effect on performance.

People management: In general, the element of human resource management refers to employee training, empowerment management, relationships and teamwork, people involvement, collectively referred to as the extent to which employees participate in the QM system (Xu et al., 2020). All people in the enterprise must engage in continuous improvement and fulfil their own role to achieve customer satisfaction, which is a measure of business performance (Gatchalian, 1997). The human factor has been proved to have a positive effect on the overall performance of an enterprise. This has been shown in previous studies by Gatchalian (1997), Xu et al. (2020). Hypothesis H4 is proposed:

H4: People management have a positive effect on performance.

Customer focus: Customers are considered an essential asset for every business. Therefore, to be successful, firms must design products according to customer requirements. Research by Cai (2009) suggests that customer-centric organisations will create an impact on customer relationships, then affect customer satisfaction and production performance. Focusing on the customer is not only an essential component of TQM practices but also a core issue of a business (Deming, 2018). Similarly, the study of Brah, Tee and Rao (2002) also confirmed that a business that wants to achieve profitable growth must build long-term value for customers. Hypothesis $\mathrm{H} 5$ is proposed:

H5: Customer focus has a positive effect on performance.

Information and analysis systems: TQM philosophy emphasises fact-based decision making and information analysis such as customer needs, production problems, achievement of improvement projects (Brah, Tee and Rao, 2002). Information and analytics help businesses ensure the availability and high quality of data, timely delivery to users such as employees, customers and suppliers (Kim et al., 2012). Prajogo (2005) also demonstrates the importance of information and analysis for business performance, specifically quality performance. Hypothesis $\mathrm{H} 6$ is proposed:

H6: Information and analysis systems have a positive effect on performance.

Supplier QM: Developing long-term relationships with suppliers is a factor that helps businesses improve organisational efficiency, including production process development, product development, and nonconformity elimination. These activities reduce costs for enterprises such as production costs, product research, and development time costs (Calvo-Mora et al., 2014; Zakuan et al., 2010). Supplier quality can improve overall performance and effective financial results through cost reduction and focus on core competencies (Xu et al., 2020). According to Zineldin and Jonsson (2000), supplier relationships can improve firm performance by increasing competitiveness. 
Hypothesis $\mathrm{H} 7$ and $\mathrm{H} 8$ are proposed:

H7: Supplier quality management has a positive impact on performance.

H8: Quality management has a positive impact on performance.

\subsection{Business Performance Factors}

Business performance: Cyert and March (1992) said that business performance is the level of meeting the objectives set forth by the enterprise initially, expressed through indicators such as net profit, market share growth, revenue and effectiveness of strategic goals, et cetera. Developing long-term relationships with suppliers is a factor that helps improve organisational performance, including process development, product development and nonconformity elimination. These activities reduce costs for enterprises such as production costs, research and development time costs (Calvo-Mora et al., 2014). Zakuan et al. (2010) also agree with the above point of view that effective supplier QM can be achieved through long-term cooperation with suppliers.

Quality performance: For manufacturing enterprises, improving product quality will help to reduce waste and improve production efficiency, thereby helping to increase return on assets (Handfield, Ghosh and Fawcett, 1998). In addition, improvements in quality will attract more customers because of higher satisfaction and loyalty, increasing sales (Ahire and Dreyfus, 2000; Handfield, Ghosh and Fawcett, 1998), enhancing competitive position (Choi and Eboch, 1998).

Customer satisfaction: Customer satisfaction is seen as a business goal (Liu and Jang, 2009). The purchase decision of customers is a measure of business performance. Contributions from customers help improve the company's innovation performance (Moilanen, Østbye and Woll, 2014). Customers are the end users of the products and are closely linked to the market, so understanding customer-relevant metrics will increase insight into current market needs (Nilsson, Johnson and Gustafsson, 2001).

Employee satisfaction: Research by Lashbrook (1997) has demonstrated that job satisfaction, job completion and employee empowerment greatly influence business performance. Matzler and Renzl (2007) pointed out that the intangible assets of the organisation are all in the skills of the employees, the future of the organisation will depend a lot on the employees as well as the customer's perception. Research by Koys (2003) also confirms these views. Long-term employees will help reduce recruitment and training costs, which is a prerequisite for increasing financial efficiency for businesses (Chi and Gursoy, 2009).

\subsection{Industry 4.0 Technology}

Industry 4.0 technology: In "The Fourth Industrial Revolution" by Klaus Schwab (2016), technology 4.0 includes business processes and production network organisation on the basis of information, communication and internet technology. 
Industry 4.0 can change the existing technology, open up possibilities for a new global industry and be the development standard of the global economic system (Popkova, Ragulina and Bogoviz, 2019). Slusarczyk et al. (2020) also suggested that businesses need to plan for digital transformation. Industry 4.0 practice barriers are significantly different across contrasting economies, which makes business performance is also affected to varying degrees (Haseeb et al., 2019). Elements of the 4.0 technology revolution such as Big data and IoT actively promote information technology, contributing to sustainable business performance. Although there have been many studies about the importance of 4.0 technology to business results, the moderating role of the relationship between QM and business performance has not been mentioned. Technology 4.0 in Jayashree, Reza and Mohiuddin (2021) have shown that it is effective and meaningful for research. Therefore, in this study, the authors chose 4.0 technology as a moderating effect to clarify the relationship between QM and business performance. Hypothesis $\mathrm{H} 9$ is proposed:

H9: Industry 4.0 has positive impact on business performance.

And hypothesis $\mathrm{H} 9 \mathrm{a}$ is also proposed:

H9a: Industry 4.0 moderates positively the relationship between quality management and business performance.

\subsection{Conceptual Model}

Studies related to the influence of QM on business performance in the world have been analysed from many different points of view, fields or research methods (Benavides-Velasco, Quintana-García and Marchante-Lara, 2014; Fotopoulos and Psomas, 2009; Xu et al., 2020). After literature review, we propose the following model below.

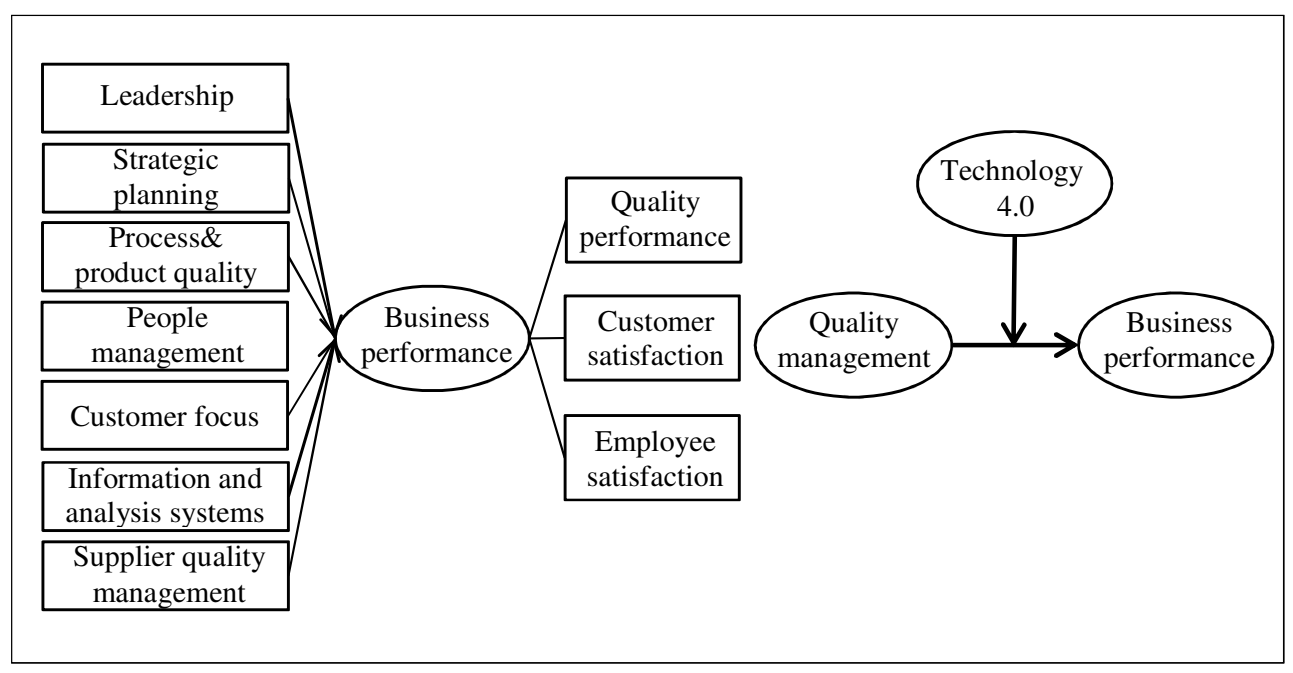

Figure 1 - The Proposed Model 


\section{METHODOLOGY}

\subsection{Qualitative Method}

The authors interview three quality and production experts and one senior executives who have worked in a manufacturing environment to review draft questionnaire. They'll be the ones to determine whether the scale being utilised is appropriate and offer comments or advice. After process, we have final questionnaire to collect data for quantitative method.

\subsection{Quantitative Method}

According to Handi et al. (2018), to measure opinions, attitudes, and perceptions of a person about an opinion, a Likert scale is suitable to be used. Therefore, we design a questionnaire with Likert scale consists of a range from 1 to 5 levels: totally disagree, disagree, normal, agree, and totally agree.

According to Cochran (1977), there are two sampling methods: probability sampling and non-probability sampling. In this research, the authors chose nonprobability sampling. The research is to survey the subjects who are employees of the QM department and production department of manufacturing firms.

According to Handi et al. (2018), the validity test is used to measure whether or not a questionnaire is valid. A questionnaire is valid if the questions or statements can be used to measure something that is relevant to the questionnaire. This research used the multivariate data analysis technique PLS-SEM using SmartPLS software. Through the evaluation of three measurement models: formative measurement model, reflective measurement model, and structural model, by using measurement indicators.

According to Hair et al. (2016), an indicator is valid if it has an outer load index $\geq 0.7$. By testing reliability based on Average Variance Extracted index (AVE $\geq 0.5)$, Composite Reliability index $(0.7 \leq \mathrm{CR} \leq 0.9)$, multicollinearity based on Variance Inflation Factor index (VIF $\leq 5$ ), individual accuracy based on Heterotrait-Monotrait Ratio (HTMT $\leq 0.85$ ). Furthermore, the bootstrapping analysis technique is appropriate for testing the observed variables in the research model. In particular, the p-value regression weights are used to test whether the hypotheses are accepted or not. From there, check which direction the variables impact by using the Original Sample index.

Finally, based on the Moderating Effect technique, the authors test the impact of the moderator on the relationship of QM to business performance by hypothesising $\mathrm{H} 9 \mathrm{a}$. 


\section{RESULT}

The survey was conducted from June 28, 2021 to August 3, 2021 with 84 respondents who are considered to have appropriately completed the survey. Based on manufacturing, there were $67.86 \%$ of respondents working at enterprises that manufacture equipment, machines and components; $32.14 \%$ were working at an agrochemical company. Based on position, $83.33 \%$ were employees; $8.33 \%$ were managers; $3.57 \%$ were department heads and $3.57 \%$ were deputy department heads. The department can be divided into two parts: $55.95 \%$ of the production department and a $44.05 \%$ quality department. Based on experience, there are $40.48 \%$ under 3 years, between 3 to under 5 years and over 5 years are equal with $29.76 \%$.

Table 1 - Measurement Value Test

\begin{tabular}{|c|l|c|c|c|c|}
\hline No & Variable & Indicator & Variance Inflation Factor (VIF) & p-value & Variable \\
\hline 1 & Quality performance & QP & 4.013 & 0.045 & Valid \\
\hline 2 & Customer satisfaction & CS & 2.139 & 0.035 & Valid \\
\hline 3 & Employee satisfaction & ES & 3.261 & 0.690 & Invalid \\
\hline
\end{tabular}

Based on Table 1, both quality performance (QP) and customer satisfaction (CS) have valid results, because they meet the statistical significance criteria (p-value $\leq 0.05)$ and are not multicollinearity (VIF $\leq 5)$. This demonstrates that, despite the fact that they are non-financial measures, they all contribute to improved financial performance and are measuring business performance. Employee satisfaction (ES), on the other hand, has a p-value of $0.690>0.05$, indicating that it is ineligible for use in measuring business performance and is thus removed from the model.

Table 2 - Validity and Reliability Test

\begin{tabular}{|c|l|c|c|c|c|c|}
\hline No & Variable & Indicator & Validity & AVE & CR & Reliability \\
\hline 1 & Leadership & LD & Valid & 0.615 & 0.827 & Reliable \\
\hline 2 & Strategic planning & SP & Valid & 0.724 & 0.887 & Reliable \\
\hline 3 & Processes and products QM & PQ & Valid & 0.750 & 0.899 & Reliable \\
\hline 4 & People management & PM & Valid & 0.673 & 0.891 & Reliable \\
\hline 5 & Customer focus & CF & Valid & 0.710 & 0.879 & Reliable \\
\hline 6 & $\begin{array}{l}\text { Information and analysis } \\
\text { systems }\end{array}$ & IS & Valid & 0.745 & 0.836 & Reliable \\
\hline 7 & Supplier QM & SQ & Valid & 0.773 & 0.872 & Reliable \\
\hline
\end{tabular}


Based on Table 2, all variables are shown to be valid and reliable because they meet the CR and AVE indexes are fit or good. All factors are consistent in terms of internal consistency reliability $(0.7 \leq \mathrm{CR} \leq 0.9)$, convergence accuracy $(\mathrm{AVE} \geq 0.5)$.

Table 3 - Model Fit Test

\begin{tabular}{|l|c|c|c|}
\hline Goodness of Fit Index & Cut-off Value & Result & Evaluation \\
\hline VIF & $\leq 5$ & From 1 to 1.038 & Fit \\
\hline R square adjusted & Expected big & $0.677(67.7 \%)$ & Fit \\
\hline Heterotrait - Monotrait Ratio (HTMT) & $\leq 0.85$ & $\max 0.842$ & Fit \\
\hline Bootstrap & $\leq 1$ & From 0.033 to 0.988 & Fit \\
\hline
\end{tabular}

Table 3 shows that all of the indexes in the Model fit Test are fit or good. The Variance Inflation Factor (VIF) result ranges from 1 to 1.038, which is less than 5 . It can be concluded that there is no multicollinearity between the variables in the model. Other criteria such as R square adjusted, individual accuracy (HTMT) and Bootstrap are also implemented and passed prior to hypothesis testing.

The next analytic step is looking at p-value on the output of regression weights based on the level of significance set to $0.05(5 \%)$ to test the statistical significance of the factors for business performance. If the p-value $\leq 0.05$, then the hypothesis is accepted and significant. The Original Sample coefficient will indicate the direction of the effect of this relationship if it is greater than 0 .

Table 4 - Hypothesis Test

\begin{tabular}{|c|c|c|c|c|}
\hline Hypothesis & Effect & Original Sample & p-values & Result \\
\hline H1 & LD $\rightarrow$ BP & 0.729 & 0.000 & Accepted \\
\hline H2 & SP $\rightarrow$ BP & 0.686 & 0.083 & Not accepted \\
\hline H3 & PQ $\rightarrow$ BP & 0.461 & 0.461 & Not accepted \\
\hline H4 & PM $\rightarrow$ BP & 0.761 & 0.000 & Accepted \\
\hline H5 & CF $\rightarrow$ BP & 0.674 & 0.000 & Accepted \\
\hline H6 & IS $\rightarrow$ BP & 0.674 & 0.000 & Accepted \\
\hline H7 & SQ $\rightarrow$ BP & 0.674 & 0.058 & Not accepted \\
\hline H9a & I4.0 moderator $\rightarrow$ BP & 0.167 & 0.042 & Accepted \\
\hline H9 & I4.0 $\rightarrow$ BP & 0.286 & 0.022 & Accepted \\
\hline H8 & QM $\rightarrow$ BP & 0.461 & 0.000 & Accepted \\
\hline
\end{tabular}




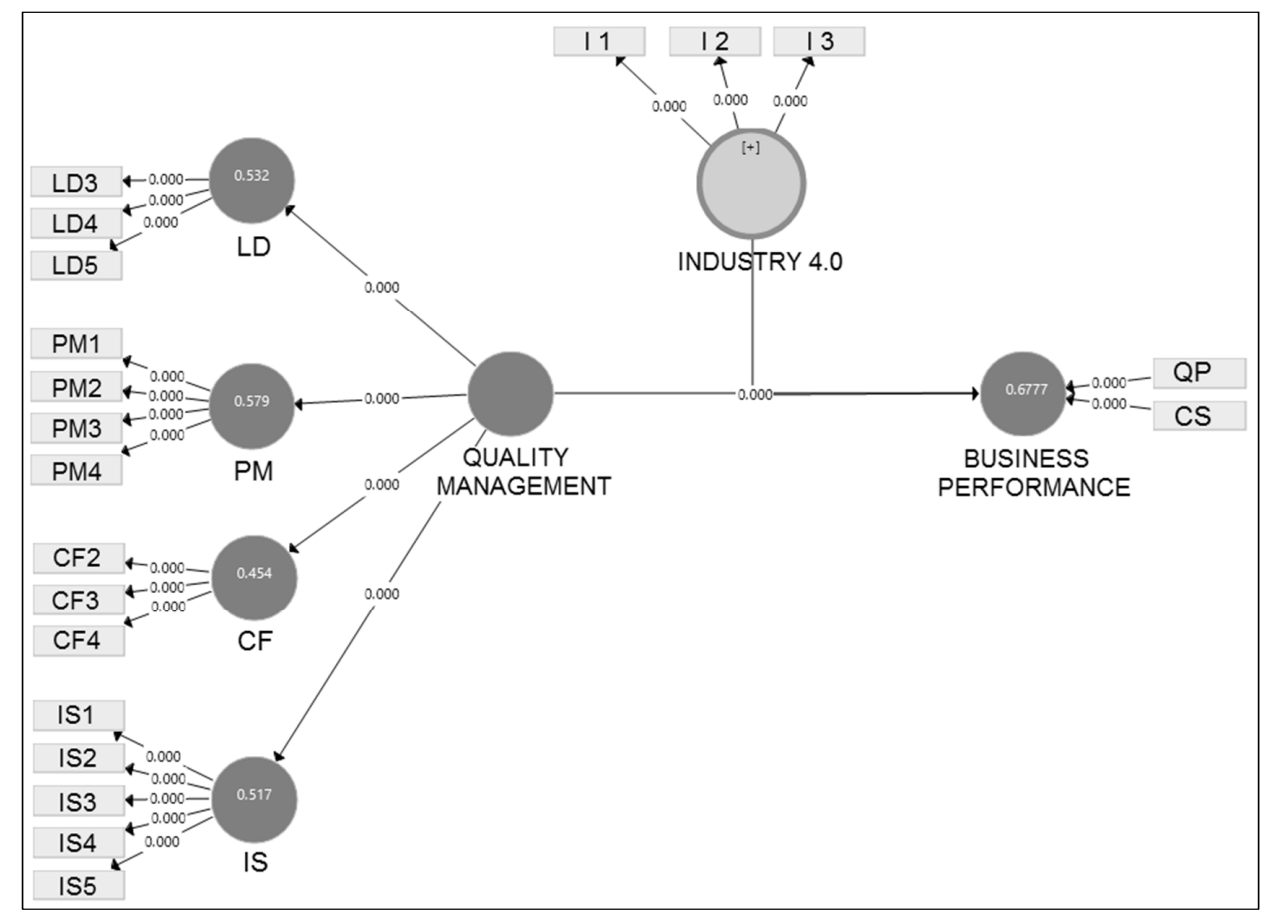

Figure 2 - The Proposed Model

The suty show that leadership has a positive effect on performance. The majority of respondents' positions were employees, who are the creators of work productivity and they often had to work directly with leaders. Therefore, their job is directly affected by leadership decisions or actions. Business performance will almost certainly improve if leaders concentrate on the importance of quality in the execution of work.

The research also proves that people management has a positive effect on performance. The human element is present in all organisational activities. Given that the majority of respondents have less than three years of work experience, there is a significant need for training and willingness to participate in projects and hone teamwork skills. So, people management is responsible for maximising human potential and thus improving business performance.

Customer focus, according to the findings, has a positive effect on performance. The survey is for those who work in the manufacturing and quality control departments. These are departments that work with regular customers. Therefore, they understand that the company's profitability is determined by its customers. The more satisfied customers are with products or services, the more productive the company becomes.

The result also indicates that information and analysis systems have a positive effect on performance. People who participate in the survey work in manufacturing firms; therefore, they must be ready to adapt rapidly to changing 
client demands at all times. Information and analysis systems can help with product design, processes, and data for production. Rapidly deploying information and analysis systems will aid in increasing labour productivity and business performance.

The result of moderator effect show that $\mathrm{p}$-value $<0.05$, relationships have an effect on each other, so the hypothesis H9a is accepted, the relationship between QM and business performance is affected by industry 4.0. The Original Sample $>0$ shows that industry 4.0 has the function of moderating the relationship between QM and business performance in a positive direction. So, incorporating industry 4.0 into a business's operations is a wise decision.

The p-value of the relationship between industry 4.0 and business performance is positive, indicating that industry 4.0 influences business performance. Industry 4.0 has a beneficial impact on business success, according to the Original Sample regression coefficient. Businesses will be able to improve their efficiency by incorporating Technology 4.0 into their manufacturing and commercial activities.

Quality management has a significant impact on business performance based on the p-value and Original Sample index. It is clear that the better QM is implemented, the better the business performance will be. As a result, QM is critical in the enterprise's production activities.

\section{CONCLUSION AND LIMITATIONS}

The analysis results of the structural model show that there are four independent variables affecting business performance: leadership, people management, customer focus, information and analysis systems. Therefore, businesses need to focus more on these four factors if they want to increase business efficiency. These variables affect the right direction. If the manufacturing enterprise does not have a clear action direction, improve employee engagement, effectively use analysis, and focus on customer's demand, it will negatively impact the company's business performance. Research also shows that industry 4.0 has a moderating effect on the relationship between $\mathrm{QM}$ and business performance. Effective application of industry 4.0 in enterprises not only helps in strict and accurate QM, but also improves business results in many aspects.

Although the study has some contributions, however, it has some limitations. Firstly, only a small number of respondents from developing countries took part in the survey. As a result, the sample size might not be representative of the entire globe. Secondly, the study did not take into account other TQM variables that impact business performance, such as devices, quality procedures and tools, data quality, etc., nor did it examine all of the criteria that measure business performance, such as social performance, green performance. 


\section{ACKNOWLEDGEMENTS}

The authors would like to thank the respondents who help us to answer the questionnaire.

\section{REFERENCES}

Ahire, S.L. and Dreyfus, P., 2000. The impact of design management and process management on quality: an empirical examination. Journal of Operations Management, [e-journal] 18(5), pp.549-575. DOI: 10.1016/S02726963(00)00029-2.

Benavides-Velasco, C., Quintana-García, C. and Marchante-Lara, M., 2014. Total quality management, corporate social responsibility and performance in the hotel industry. International Journal of Hospitality Management, [e-journal] 41, p.77-87. DOI: 10.1016/j.ijhm.2014.05.003.

Brah, S.A., Tee, S.S.L. and Rao, B.M., 2002. Relationship between TQM and Performance of Singapore Companies. International Journal of Quality \& Reliability Management, 19(4), pp.356-379.

Cai, S., 2009. The importance of customer focus for organisational performance: a study of Chinese companies. International Journal of Quality \& Reliability Management, [e-journal] 26(4), pp.369-379. DOI: 10.1108/02656710910950351.

Calvo-Mora, A., Ruiz-Moreno, C., Picón-Berjoyo, A. and Cauzo-Bottala, L., 2014. Mediation effect of TQM technical factors in excellence management systems. Journal of Business Research, [e-journal] 67(5), pp.769-774. DOI: 10.1016/j.jbusres.2013.11.042.

Chi, C.G. and Gursoy, D., 2009. Employee satisfaction, customer satisfaction, and financial performance: An empirical examination. International Journal of Hospitality Management, [e-journal] 28(2), pp.245-253. DOI: 10.1016/j.ijhm.2008.08.003.

Choi, T.Y. and Eboch, K., 1998. The TQM paradox Relations among TQM practices, plant performance, and customer satisfaction. Journal of Operations Management, 17(1), pp.59-75.

Cochran, W.G., 1977. Sampling techniques. New York: John Wiley \& Sons.

Cyert, R.M. and March, J.G., 1992. A Behavioral Theory of the Firm. Oxford: Basil Blackwell Publishing.

Deming, W.E., 2018. The New Economics for Industry, Government, Education. London: MIT.

Douglas, T.J. and Judge, W.Q., 2017. Total Quality Management Implementation and Competitive Advantage: The Role of Structural Control and Exploration. Academy of Management Journal, [e-journal] 44(1), pp.158-169. DOI: 10.5465/3069343. 
Filip, F.C. and Marascu-Klein, V., 2013. Analysis of process and product quality assurance. In: Marascu-Klein, V., Advances in Production, Automation and Transportation Systems. Brasov, Romania, 1-3 June 2013. WSEAS Press.

Fotopoulos, C.V. and Psomas, E.L., 2010. The structural relationships between TQM factors and organisational performance. TQM Journal, [e-journal] 22(5), pp.539-552. DOI: 10.1108/17542731011072874.

Gatchalian, M.M., 1997. People empowerment: the key to TQM success. The TQM Magazine, 9(6), pp.429-433.

Hair, J.F., Sarstedt, M., Matthews, L. and Ringle, C.M., 2016. Identifying and treating unobserved heterogeneity with FIMIX-PLS: part I - method. European Business Review, [e-journal] 28(1), pp.63-76. DOI: 10.1108/EBR-09-2015-0094.

Handfield, R., Ghosh, S. and Fawcett, S., 1998. Quality-Driven Change and its Effects on Financial Performance. Quality Management Journal, 5(3), pp.13-30.

Handi, H., Hendratono, T., Purwanto, E. and Ihalauw, J.J., 2018. The Effect of EWOM and Perceived Value on the Purchase Decision of Foods by Using the GoFood Application as Mediated by Trust. Quality Innovation Prosperity, [ejournal] 22(2), pp.112-127. DOI: 10.12776/qip.v22i2.1062.

Haseeb, M., Hussain, H.I., Slusarczyk, B. and Jermsittiparsert, K., 2019. Industry 4.0: A Solution towards Technology Challenges of Sustainable Business Performance. Social Sciences Journal, 8(5), pp.154-178. DOI: 10.3390/socsci8050154.

Jaafreh, A.B. and Al-abedallat, A.Z., 2013. The Effect of Quality Management Practices on Organizational Performance in Jordan: An Empirical Study. International Journal of Financial Research, [e-journal] 4(1), pp.93-109. DOI: 10.5430/ijfr.v4n1p93.

Jayashree, S., Reza, M.N.H. and Mohiuddin, M., 2021. Impact of Cleaner Production and Environmental Management Systems on Sustainability: The Moderating Role of Industry 4.0. Earth and Environmental Science, [e-journal] 795, p.012013. DOI: 10.1088/1755-1315/795/1/012013.

Kerzner, H., 2001. Strategic planning for project management using a project management maturity model. New York: John Wiley \& Sons.

Kim, S.M., Kang, S.-W., Kwon, O., Chung, D. and Pan, C.-H., 2012. Fucoxanthin as a major carotenoid in Isochrysis aff. galbana: Characterisation of extraction for commercial application. Journal of the Korean Society for Applied Biological Chemistry, [e-journal] 55, pp.477-483. DOI: 10.1007/s13765-0122108-3.

Kotter, J.P., 1988. The Leadership Factor. New York: Free Press.

Koys, D.J., 2003. How the achievement of human-resources goals drives restaurant performance. The Cornell Hotel and Restaurant Administration Quarterly, [e-journal] 44(1), pp.17-24. DOI: 10.1177/0010880403441002. 
Lashbrook, W.B., 1997. Business Performance, Employee Satisfaction, and Leadership Practices. Performance Improvement Journal, 36(5), pp.29-33.

Liu, Y. and Jang, S.C., 2009. Perceptions of Chinese restaurants in the U.S.: What affects customer satisfaction and behavioral intentions?. International Journal of Hospitality Management, [e-journal] 28, pp.338-348. DOI: 10.1016/j.ijhm.2008.10.008.

Madu, C.N., Kuei, C.H. and Jacob, R.A., 1996. An empirical assessment of the influence of quality dimensions on organisational performance. International Journal of Production Research, [e-journal] 34(7), pp.1943-1962. DOI: 10.1080/00207549608905006.

Magd, H., Negi, S. and Ansari, M.S.A., 2021. Effective TQM Implementation in the Service Industry: A Proposed Framework. Quality Innovation Prosperity, [ejournal] 25(2), pp.95-129. DOI: 10.12776/QIP.V25I2.1594.

Matzler, K. and Renzl, B., 2007. Assessing asymmetric effects in the formation of employee satisfaction. Tourism Management Journal, 28, pp.1093-1103.

Moilanen, M., Østbye, S. and Woll, K., 2014. Non-R\&D SMEs: External knowledge, absorptive capacity and product innovation. Small Business Economics, [e-journal] 43(2), pp.447-462. DOI: 10.1007/s11187-014-9545-9.

Nair, A., 2006. Meta-analysis of the relationship between quality management practices and firm performance-implications for quality management theory development. Journal of Operations Management, [e-journal] 24(6), pp.948-975. DOI: 10.1016/j.jom.2005.11.005.

Nickols, F., 2016. Strategy, strategic management, strategic planning and strategic thinking. Management Journal, 1(1), pp.4-7.

Nilsson, L., Johnson, M.D. and Gustafsson, A., 2001. The Impact of Quality Practices on Customer Satisfaction and Business Results: Product Versus Service Organisations. Journal of Quality Management, [e-journal] 6(1), pp.5-27. DOI: 10.1016/S1084-8568(01)00026-8.

Palmberg, K., 2009. Exploring process management: are there any widespread models and definitions?. TQM Journal, [e-journal] 21(2), pp.203-215. DOI: 10.1108/17542730910938182.

Pittaway, L., Robertson, M., Munir, K., Denyer, D. and Neely, A., 2004. Networking and Innovation: A Systematic Review of the Evidence. International Journal of Management Reviews, [e-journal] 5-6(3-4), pp.137-168. DOI: 10.1111/j.1460-8545.2004.00101.x.

Popkova, E.G., Ragulina, Y.V., and Bogoviz, A.V. eds., 2019. Industry 4.0: Industrial Revolution of the 21st Century. Cham: Springer International Publishing AG. 
Prajogo, D.I., 2005. The Comparative Analysis of TQM Practices and Quality Performance Between Manufacturing and Service Firms in Australia. International Journal of Service Industry Management, [e-journal] 16(3), pp.217228. DOI: 10.1108/09564230510601378.

Schwab, K., 2016. The Fourth Industrial Revolution. Geneva: World Economic Forum.

Sila, M.E.I., 2003. Important relationship between TQM factors and business performance. International Journal of Operations \& Production Management, 41(2), pp.235-268.

Ślusarczyk, B., Tvaronavičienė, M., Ul Haque, A. and Oláh, J., 2020. Predictors of industry 4.0 technologies affecting logistic enterprises' performance: International perspective from economic lens. Technological and Economic Development of Economy Journal, [e-journal] 26(6), pp.1263-1283. DOI: 10.3846/tede.2020.13376.

Talib, F., Rahman, Z. and Qureshi, M.N., 2013. An empirical investigation of relationship between total quality management practices and quality performance in Indian service companies. International Journal of Quality \& Reliability Management, [e-journal] 30(3), pp.280-318. DOI: 10.1108/02656711311299845.

Xu, L., Peng, X., Pavur, R. and Prybutok, V., 2020. Quality management theory development via meta-analysis. International Journal of Production Economics, [e-journal] 229, p.107759. DOI: 10.1016/j.ijpe.2020.107759.

Yang, C., 2006. The impact of human resource management practices on the implementation of total quality management: An empirical study on high-tech firms. The TQM Magazine, [e-journal] 18(2), pp.162-173. DOI: 10.1108/09544780610647874.

Zakuan, N.M., Yusof, S.M., Laosirihongthong, T. and Shaharoun, A.M., 2010. Proposed relationship of TQM and organisational performance using structured equation modelling. Total Quality Management \& Business Excellence, [ejournal] 21(2), pp.185-203. DOI: 10.1080/14783360903550020.

Zaleznik, A., 2004. Managers and Leaders: Are They Different? Harvard Business Review, [online] 1 January 2004. Available at: <https://hbsp.harvard.edu/product/R0401G-PDF-ENG> [Accessed 28 November 2021].

Zineldin, M. and Jonsson, P., 2000. An examination of the main factors affecting trust/commitment in supplier-dealer relationships: an empirical study of the Swedish wood industry. The TQM Magazine, 12(4), pp.245-266. 


\section{ABOUT AUTHORS}

Nu Nguyen ${ }^{0000-0002-6709-1731}$ (N.N.) - Department of Industrial Management, Faculty of Economics, HCMC University of Technology and Education, Vietnam, email: nunguyent713@gmail.com.

Chuong Nguyen ${ }^{0000-0002-8062-1522}$ (C.N.) - Department of Industrial Management, Faculty of Economics, HCMC University of Technology and Education, Vietnam, e-mail: hoakimchuong@gmail.com.

Hieu Nguyen ${ }^{0000-0002-5138-2032}$ (H.N.) - Faculty of Economics, HCMC University of Technology and Education, Vietnam, e-mail: hieunk@hcmute.edu.vn.

Van Nguyen ${ }^{0000-0001-6950-6868}$ (V.N.) - PhD, Faculty of Management and Economics, Tomas Bata University in Zlín, Czech Republic, e-mail: t5nguyen@utb.cz.

\section{AUTHOR CONTRIBUTIONS}

Conceptualization, N.N. and C.N.; Methodology, N.N., C.N. and V.N.; Software, N.N.; Validation, N.N., V.N. and H.N.; Formal analysis, N.N. and C.N.; Investigation, N.N, C.N. and V.N.; Resources, N.N.; Data curation, N.N. and H.N.; Original draft preparation, N.N. and C.N.; Review and editing, V.N. and H.N.; Visualization, V.N. and H.N.; Supervision, V.N. and H.N.

\section{CONFLICTS OF INTEREST}

The authors declare no conflict of interest. The funders had no role in the design of the study; in the collection, analyses, or interpretation of data; in the writing of the manuscript, or in the decision to publish the results.

(C) 2021 by the authors. Submitted for possible open access publication under the terms and conditions of the Creative Commons Attribution (CC-BY) license (http://creativecommons.org/licenses/by/4.0/). 